\title{
KAKO SE ODRASLI SPREMINJAMO Osebnostni razvoj in socialna komunikacija
}

\section{avtorica: mag. Daniela Brečko}

S zorimo le v mladosti, in da je naš osebnostni razvoj zaključen približno s koncem obdobja adolescence. Potemtakem naj bi odraslost predstavljala relativno mirno obdobje brez velikih sprememb in pričakovanj. Toda prvi dvomi v stabilno odraslost so se začeli z opazovanjem in znanstvenim preučevanjem krize srednjih let. Ali je res vse, kar dosežemo v življenju, odvisno od zgodnjega otroštva?

Delo Daniele Brečko nam daje imeniten vpogled $\mathrm{v}$ zadevno problematiko, začenši z obširno razpravo, kaj je osebnost in kaj je razvoj. V svojem delu se je lotila tudi zgodovinskega pregleda pogledov na osebnost in razvoj, ker so jasno vidni premiki $\mathrm{v}$ razmišljanju in gledanju na človeka. Prikazani so pogledi različnih svetovnih mislecev, kronološko zaporedje paradigme pa daje slutiti, da razmišljanje o osebnosti še zdaleč ni zaključeno.

Avtorica se dokaj podrobno ukvarja z vprašanjem razlik med otroštvom in odraslostjo in izpostavi nekaj najbolj temeljnih ločnic. Vseskozi pa pri pisanju izhaja iz predpostav$\mathrm{ke}$, da je človek in potemtakem osebnost predvsem socialen konstrukt, njegov razvoj in zorenje pa sta odvisna tudi od vsakokratnih družbenih razmer $\mathrm{v}$ najširšem pomenu te besede.

In kako osebnostno zorimo in se razvijamo? Avtorica ponudi v razmišljanje več agensov, vse pa je moč razvrstiti v kontinuum različnih socialnih okolij, v katerem človek zadovoljuje svoje potrebe in $\mathrm{v}$ katerih biva. Tako jih razvrsti na tri socialna okolja in sicer družino, poklicno okolje ter okolje, v katerem posameznik preživlja svoj prosti čas.

V svojem delu izpostavi pomen različnih socialnih vlog, ki jih v življenju prevzemamo in izpolnjujemo norme, vzorce in pravila, ki se vežejo na določeno socialno vlogo in jih je $\mathrm{v}$ zgodovinskem razvoju postavila družba ter njeni subjekti.

Posebej izpostavi pomen socialne komunikacije in trdi, da je družbena interakcija sporočil ključen faktor osebnostnega razvoja. Za zaključek pa lahko preberemo še zanimiv pogled na osebnostni razvoj ter nenehne spremembe v okolju.

Daniela Brečko se

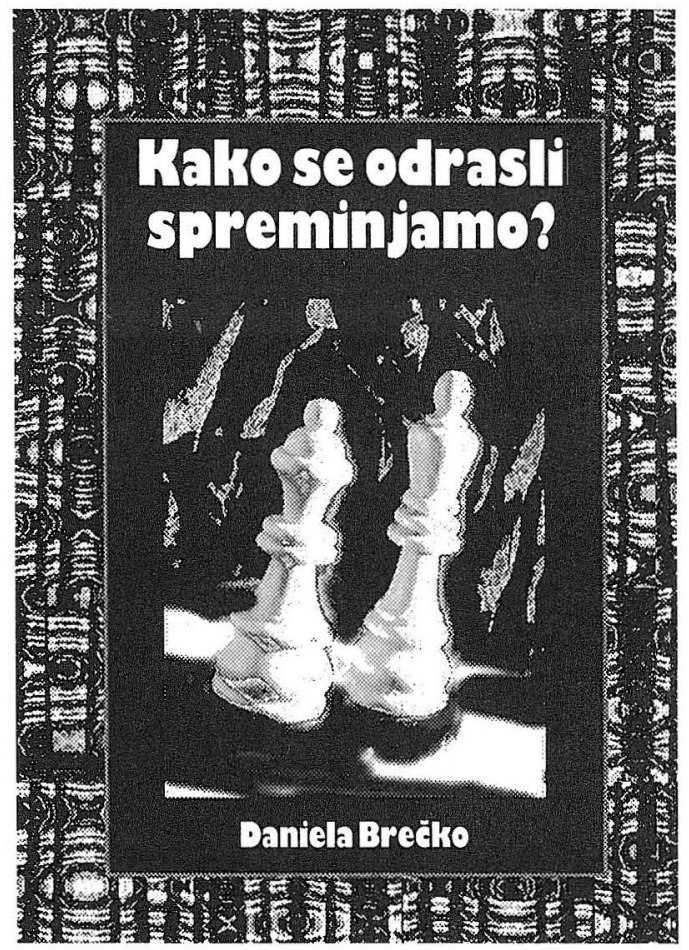
nam s pričujočo knjigo predstavlja kot resna raziskovalka osebnosti odraslih. Obsežno in včasih nehvaležno problematiko je naredila dostopno in pregledno, tako da nam je podala velik del presojanja osebnosti in osebnostnega razvoja in hkrati ponudila $v$ razmišljanje tudi cel kup drobnih vprašanj o nas samih.

dr. Zdenko Medveš

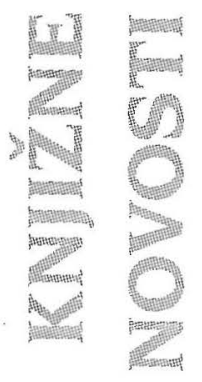

